\title{
Risk of birth defects in children conceived by artificial oocyte activation and intracytoplasmic sperm injection: a meta- analysis
}

\author{
Rui Long, Meng Wang, Qi Yu Yang, Shi Qiao Hu, Li Xia Zhu* and Lei Jin *io
}

\begin{abstract}
Background: Whether artificial oocyte activation (ICSI-AOA) will increase the risk of birth defects remains controversial. Thus, we performed this study to evaluate the risk of birth defects and further compare the incidence of different birth defects types (chromosomal aberrations and non-chromosomal aberrations) in children conceived by ICSI-AOA and conventional intracytoplasmic sperm injection (ICSI) in an enlarged sample size.

Method: A comprehensive review of the literatures comparing birth defects in children conceived by ICSI-AOA and conventional ICSI by October 2020 was performed in PubMed, Embase, Cochrane Libraries, Web of Science, and Chinese databases including China National Knowledge Infrastructure, China Biology Medicine disc and Wan Fang. Risk ratios (RR) and 95\% confidence intervals (Cl) were calculated.

Results: Five studies were included in the final analysis. Compared with conventional ICSI, ICSI-AOA did not increase the birth defects rate ( $R R=1.27,95 \% \mathrm{Cl} 0.70-2.28)$ of children. Furthermore, in a subgroup analysis, birth defects were classified into two types (chromosomal aberrations and non-chromosomal aberrations) in four studies and no statistical difference were revealed.

Conclusion: Our analysis indicates that ICSI-AOA represents no significant difference in the prevalence of major birth defects or types of birth defects (chromosomal aberrations and non-chromosomal aberrations) comparing with conventional ICSI. This conclusion may provide clinicians evidence-based support in patient counseling and instruction of the application and safety concern about ICSI-AOA.
\end{abstract}

Keywords: Birth defects, AOA, ICSI, Meta-analysis, Chromosomal aberrations

\section{Background}

Since the first intracytoplasmic sperm injection (ICSI) pregnancy were reported in the early 1990s [1], ICSI has been used as an effective method for assisted reproductive technology (ART), especially for patients with suboptimal semen parameters or zero or low fertilization

*Correspondence: zhulixia027@163.com; leijintongjih@qq.com Reproductive Medicine Center, Tongji Hospital, Tongji Medical College, Huazhong University of Science and Technology, 1095 Jiefang Ave, Wuhan 430030, China rates after conventional in vitro fertilization (IVF). However, ICSI results in average fertilization rates of 70\% [2], total fertilization failure (TFF) still occurs in $1-3 \%$ cycles and can recur in subsequent cycles, even when a sufficient number of oocytes and motile spermatozoa are available $[3,4]$.

Oocyte activation which induces the calcium oscillations to raise the intracellular calcium levels in the oocyte after spermatozoon-oocyte fusion [5], is a master key to initiate all the cytological changes in fertilized

(c) The Author(s). 2020 Open Access This article is licensed under a Creative Commons Attribution 4.0 International License, which permits use, sharing, adaptation, distribution and reproduction in any medium or format, as long as you give appropriate credit to the original author(s) and the source, provide a link to the Creative Commons licence, and indicate if changes were made. The images or other third party material in this article are included in the article's Creative Commons licence, unless indicated otherwise in a credit line to the material. If material is not included in the article's Creative Commons licence and your intended use is not permitted by statutory regulation or exceeds the permitted use, you will need to obtain permission directly from the copyright holder. To view a copy of this licence, visit http://creativecommons.org/licenses/by/4.0/. The Creative Commons Public Domain Dedication waiver (http://creativecommons.org/publicdomain/zero/1.0/) applies to the data made available in this article, unless otherwise stated in a credit line to the data. 
oocyte [6, 7]. Therefore, oocyte activation failure is generally regarded as the principal cause of $\operatorname{TFF}[4,8,9]$.

Artificial oocyte activation (AOA) is considered as an effective method to improve fertilization rate after TFF [10]. A variety of activating oocyte methods have been applied in human assisted reproduction treatment, including physical, mechanical or chemical stimuli, mainly aiming to initiate artificial $\mathrm{Ca}^{2+}$ rises in the oocyte cytoplasm [11]. Previous study has reported that the fertilization rate increased from 25 to $48 \%$ after using AOA [10]. And the applications of these methods in clinical have been previously reviewed [12-14].

However, AOA procedure, which includes an additional manipulation on the injected oocyte, and incubation in activating agents, may interfere the cell metabolism or embryo development. As previously reported, gamete manipulations, which were both involved in AOA and conventional ICSI procedures were considered to be possible risk factors in birth defects [15]. The calcium rises induced artificially are not able to mimic calcium oscillations in physiological conditions precisely and little has been known yet about the possible side effects of ionophores on post-implantation embryo development [14]. Therefore, there is always a concern whether the children conceived by ICSI-AOA have a poor neonatal outcome. Previous studies have demonstrated that there are no significant differences in gestational week, birth weight, preterm birth rate or gender ratio between conventional ICSI and ICSI-AOA [15-19]. However, regarding the aspect of birth defects, some publications have reported increased risks in infants born after ICSI-AOA compared with those after conventional ICSI $[19,20]$. Whereas, some studies held the opposite views that ICSI-AOA did not affect the incidence rate of birth defects $[10,17,18,21,22]$. In addition, the prevalence of chromosomal anomalies has been reported to be higher in conventional ICSI pregnancies [23, 24]. Considering that AOA takes place during the time of meiotic spindle orientation and completion of meiosis [25], there is probably a higher chromosomal aberrations (CA) risk to children conceived by ICSI-AOA. Therefore, it is also necessary to assess the risk of birth defects type, chromosomal aberrations (CA) and nonchromosomal aberrations (NCA), respectively.

Due to the indications and the unknown safety problems, ICSI-AOA is not considered as a routine practice of ART yet, which is only suitable for patients with proper indications, including low or zero fertilization in the previous ICSI cycles or poor quality of sperm. The number of babies born from infertile patients undergoing ICSI-AOA was limited, so that the sample size of current studies was too small to draw a concluded outcome, especially in a single center. This meta-analysis aimed to enlarge born babies sample size to address the safety of AOA by comparing the risk of birth defects in children conceived by ICSI-AOA and conventional ICSI and assess the risk of birth defects type (CA and NCA).

\section{Materials and methods}

The proposed PRISMA (Preferred Reporting Items for Systematic Reviews and Meta-Analyses) guidelines were followed to report the present review [26].

\section{Search strategy}

We aimed to identify all relevant studies that compare the outcome of children conceived by ICSI-AOA and conventional ICSI. A systematic literature search was conducted of PubMed, Embase, Cochrane Libraries, Web of Science, and Chinese databases including China National Knowledge Infrastructure (CNKI), China Biology Medicine disc (CBM) and Wan Fang. All publications appearing before October 2020 in these databases were included. The following terms were used, adjusting for each database as necessary: ((Calcium ionophore) AND ((Intracytoplasmic sperm injection) OR ICSI)) AND Oocyte activation) AND (((C) Congenital abnormalities) OR Birth defects) OR malformations) OR follow up). Additionally, we hand-searched the reference list from included trials and similar reviews, and all citations identified were reviewed, irrespective of language. Two independent investigations reviewed study titles and abstracts, and studies that satisfied the inclusion criteria were retrieved for full-text assessment. The search strategy and included studies are shown in Fig. 1.

\section{Selection criteria}

Studies were included if 1) the exposure of interest was ICSI-AOA or conventional ICSI; 2) the outcome of interest was birth defects; 3) comparison of ICSI-AOA to conventional ICSI; 4) risk ratio (RR) with $95 \%$ confidence intervals $(\mathrm{CI})$ provided or could be calculated; 5) the study was published in English or Chinese. The exclusion standard was that 1) studies without full data; 2) studies were case reports or reviews; 3 ) studies with inappropriate comparison group or without control subjects.

\section{Data extraction}

Two reviewers independently reviewed all the articles, and identified the information from each study blindly. Quantitative data were collected as follows: authors, publication year, geographic region, study design, sample size of ICSI-AOA and conventional ICSI, the number and the system of birth defects and adjustment for confounders, and other related information. Study authors were contacted for the details to ensure accuracy in the review. The data were checked by other investigators. Disagreement between reviewers regarding data 


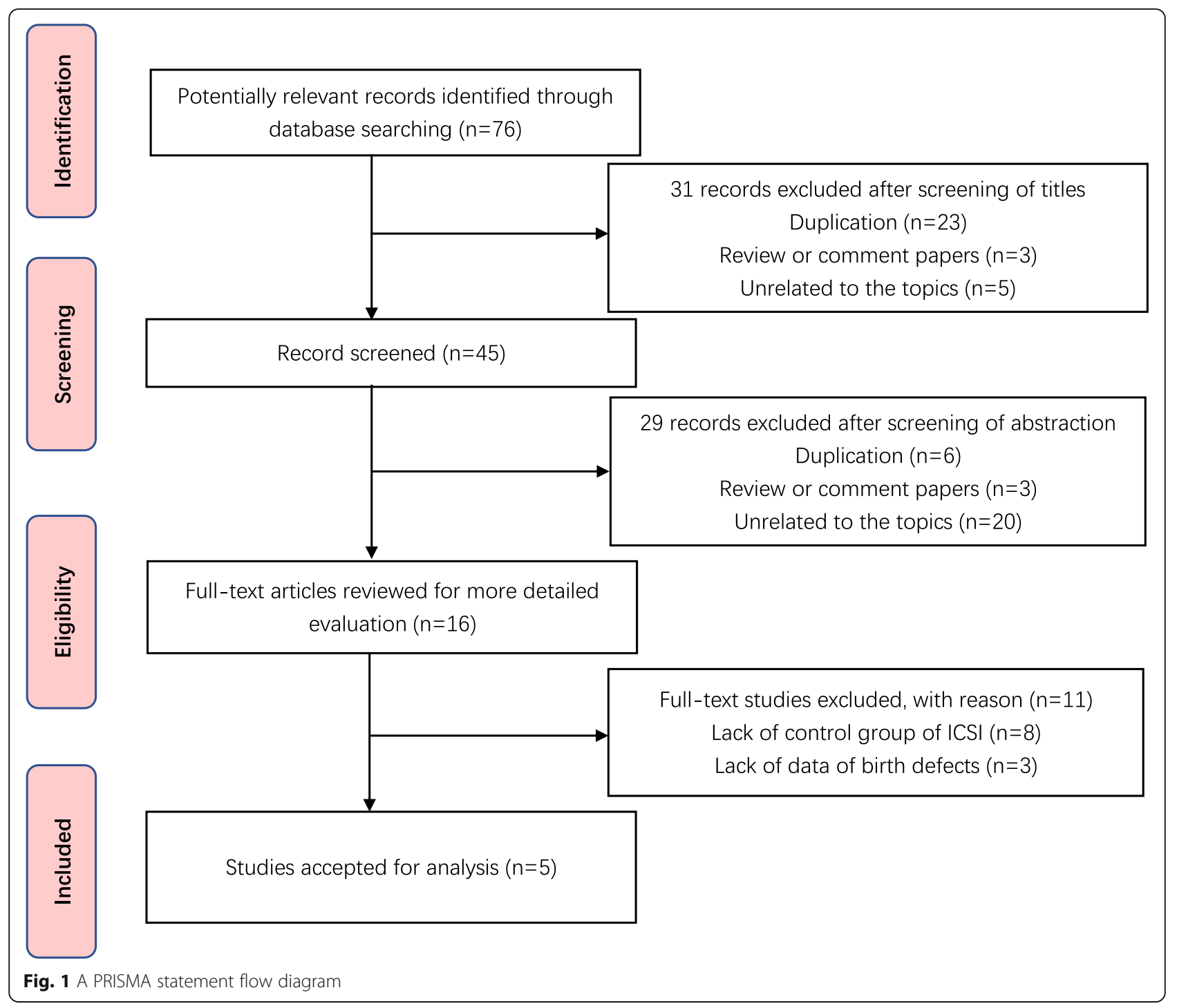

abstraction were resolved through discussion. Two independent reviewers assessed risk for bias according to the PRISMA recommendations [26].

\section{Assessment of study quality}

Newcastle-Ottawa Scale which has eight items was used to assess the quality of the studies [27]. One or two points were awarded for each criterion and the points were added up to compare study quality in a quantitative manner. Total points of $<7$ and $\geq 7$ were assigned for low and high quality of studies, respectively. Two reviewers carried out the assessment independently. Any disagreements were resolved through discussion until consensus was reached.

\section{Data synthesis}

Due to the rare number of the birth defects, we assumed equivalence of the odds ratio and $R R$, and regarded $R R$ as an effective measure of the relationship between AOA/ICSI and risk of birth defects and chromosomal aberrations across studies. Statistical heterogeneity among studies was evaluated by using the $\mathrm{Q}$ statistic (significance level at $P<0.1$ ), and the $\mathrm{I}^{2}$ statistic (significance level at $\mathrm{I}^{2}>50 \%$ ). A fix-effected model was used to calculated RR and 95\% CI if the homogeneous test was not significant $(P>0.1)$. Otherwise, a random-effects model was used. Publication bias was assessed by funnel plots and the Begg's test (significance level at $P<0.1$ ). All statistical tests were calculated using the Review Manager 5.1 software.

\section{Result}

Study inclusion and basic

Through database searching, 76 potential eligible records were found. Of these, 31 were not relevant and 29 were duplicates. Full-text reading of remained 16 studies was 
retrieved for review, 10 were journal articles whereas 6 were conference abstracts. Eleven studies were excluded because 8 trials didn't compare AOA to ICSI and 3 trials didn't involve the data of birth defects. Finally, 5 studies were included [15-18, 28]. Reviewers had perfect agreement in selecting these 5 studies using the stated eligibility criteria.

\section{Study characteristics}

Characteristics of included studies, published between 2013 and 2019, which involved 5506 conventional ICSI infants and 316 ICSI-AOA infants, are summarized in Table 1. The sample size of conventional ICSI and ICSIAOA in each study ranged from 89 to 2442 and 18-95, respectively. Furthermore, $80 \%$ of the studies stratified birth defects to CA and NCA.

All the included studies were retrospective in nature and activated oocyte by chemical stimuli, including ionomycin $[17,18,28], \mathrm{Ca}^{2+}$ ionophore $[15,16]$ or $\mathrm{SrCl}_{2}$ [16], which was summarized in Table 1. Due to the lack of a uniform standard, different indications of AOA were used in the included studies. Deemeh et al. [18] performed ICSI-AOA with previous failed or low $(<40 \%)$ fertilization rate and $100 \%$ sperm abnormality of different types. Miller et al. [15] offered the AOA procedure for patients who had failed fertilization after one ICSI procedure in the presence of at least five mature oocytes without oocyte abnormality or had $<10 \%$ fertilization rate. In the study of Bin Li et al. [17], patients with ICSIAOA should meet one of the following criteria: $\leq 50 \%$ ICSI fertilization rate; good quality embryo rate $\leq 30 \%$; the presence of severe oligoasthemoteratozoospermia; surgically retrieved sperms from testicular sperm aspiration (TESA) or percutaneous epididymal sperm aspiration (PESA). The other two studies $[16,28]$ were not mentioned their indications.

Three of them $[15,17,18]$ only included major birth defects and showed the specific organ system involvement which are summarized in Table 2. Data about birth defects were collected from pediatric report or questionnaires, and then reviewed by pediatrician or boardcertified medical geneticist. The remained studies [16, 28] did not mention these details about birth defects. Some studies $[16,18]$ monitored the occurrence of birth defect in the offspring at least 1 year after birth. Another two studies diagnosed birth defects only at birth $[15,17]$. And one study [28] did not mention about the follow-up time. Nakajo et al. [16] divided the conventional ICSI into three sub-groups, ejaculated sperm ICSI group (ejICSI), testicular sperm extraction group (TESE) and in vitro maturation group (IVM). It is well known that testicular sperm have higher rates of aneuploidies and diploidy, which means a higher incidence of congenital defect [29]. Therefore, we excluded the cycles used testicular sperm to avoid any bias in the results. The other studies assessed the birth defects in conventional ICSI and ICSI-AOA, respectively.

Four studies $[16-18,28]$ only included the birth defects of live birth and one study [15] included live birth and terminations of pregnancy for fetal anomaly. Consanguineous marriages of first-cousin union were included in one study [18] and the consanguineous marriages rate was $29.1 \%$, within the reported ranges of first-cousin union previously reported in that country. Total number of conventional ICSI and ICSI-AOA involved in birth defects types is summarized in Table 3.

Table 1 Characteristics of included studies of birth defects in babies from conventional ICSI and ICSI-AOA pregnancies

\begin{tabular}{|c|c|c|c|c|c|c|c|c|c|c|}
\hline \multirow{2}{*}{$\begin{array}{l}\text { Author(s) } \\
\text { Publication } \\
\text { year }\end{array}$} & \multirow[t]{2}{*}{ Location } & \multirow[t]{2}{*}{ Study design } & \multirow{2}{*}{$\begin{array}{l}\text { Time- } \\
\text { period }\end{array}$} & \multirow{2}{*}{$\begin{array}{l}\text { Length } \\
\text { of } \\
\text { follow- } \\
\text { up }\end{array}$} & \multirow{2}{*}{$\begin{array}{l}\text { Included } \\
\text { study } \\
\text { population }\end{array}$} & \multirow{2}{*}{$\begin{array}{l}\text { Methods } \\
\text { of oocyte } \\
\text { activation }\end{array}$} & \multicolumn{2}{|c|}{ Conventional-ICSI } & \multicolumn{2}{|l|}{ ICSI-AOA } \\
\hline & & & & & & & $\begin{array}{l}\text { No. of } \\
\text { children } \\
\text { (singletons/ } \text { multiples) } \\
\text { mu }^{\mathrm{a}}\end{array}$ & $\begin{array}{l}\text { Children with } \\
\text { birth defects }\end{array}$ & 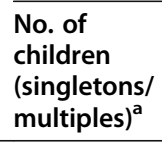 & $\begin{array}{l}\text { Children with } \\
\text { birth defects }\end{array}$ \\
\hline $\begin{array}{l}\text { Deemeh } \\
\text { (2015) [18] }\end{array}$ & Iran & $\begin{array}{l}\text { Historical } \\
\text { cohort study }\end{array}$ & $\begin{array}{l}2008- \\
2010\end{array}$ & $\begin{array}{l}1-30 \\
\text { months }\end{array}$ & Live births & ionomycin & $89(67 / 22)$ & $2(2.2 \%)$ & $79(68 / 2019)$ & $0(0 \%)$ \\
\hline $\begin{array}{l}\text { Nakajo } \\
(2016) \text { [16] }\end{array}$ & Japan & $\begin{array}{l}\text { Retrospective } \\
\text { cohort study }\end{array}$ & $\begin{array}{l}1995- \\
2014\end{array}$ & 6 years & Live births & $\begin{array}{l}\mathrm{Ca}^{2+} \\
\text { ionophore/ } \\
\mathrm{SrCl}_{2}\end{array}$ & $\begin{array}{l}1978(1640 / \\
338)\end{array}$ & 75 (3.8\%) & $62(51 / 11)$ & $2(3.2 \%)$ \\
\hline $\begin{array}{l}\text { Miller (2016) } \\
\text { [15] }\end{array}$ & Israel & $\begin{array}{l}\text { Retrospective } \\
\text { cohort study }\end{array}$ & $\begin{array}{l}2006- \\
2014\end{array}$ & Birth & $\begin{array}{l}\text { Live births } \\
\text { and TOP }\end{array}$ & $\begin{array}{l}\mathrm{Ca}^{2+} \\
\text { ionophore }\end{array}$ & $\begin{array}{l}426(315 / \\
111)\end{array}$ & $26(6.1 \%)$ & $62(51 / 11)$ & $6(9.7 \%)$ \\
\hline $\begin{array}{l}\text { Li B (2019) } \\
{[17]}\end{array}$ & China & $\begin{array}{l}\text { Retrospective } \\
\text { cohort study }\end{array}$ & $\begin{array}{l}2011- \\
2016\end{array}$ & Birth & Live births & ionomycin & $\begin{array}{l}2442(1504 / \\
938)\end{array}$ & $31(1.3 \%)$ & $95(59 / 36)$ & $2(2.1 \%)$ \\
\hline $\begin{array}{l}\text { Kobayashi } \\
\text { (2013) [28] }\end{array}$ & Japan & $\begin{array}{l}\text { Retrospective } \\
\text { cohort study }\end{array}$ & $\begin{array}{l}2006- \\
2012\end{array}$ & $\begin{array}{l}\text { Not } \\
\text { known }\end{array}$ & Live births & ionomycin & $\begin{array}{l}571 \text { (Not } \\
\text { known) }\end{array}$ & $8(1.4 \%)$ & $\begin{array}{l}18 \text { (Not } \\
\text { known) }\end{array}$ & $1(5.5 \%)$ \\
\hline Total & & & & & & & 5506 & $142(2.6 \%)$ & 316 & $11(3.5 \%)$ \\
\hline
\end{tabular}

ICSI intracytoplasmic sperm injection, $A O A$ artificial oocyte activation, TOP terminal of pregnancy

${ }^{a}$ Multiples including twins and triplets 
Table 2 Number of birth defects in specific organ system from included studies

\begin{tabular}{lllllllll}
\hline Author(s) & $\begin{array}{l}\text { Specific } \\
\text { organ system }\end{array}$ & $\begin{array}{l}\text { Circulatory } \\
\text { system }\end{array}$ & $\begin{array}{l}\text { Genitourinary } \\
\text { system }\end{array}$ & $\begin{array}{l}\text { Musculoskeletal } \\
\text { system }\end{array}$ & $\begin{array}{l}\text { Digestive } \\
\text { system }\end{array}$ & $\begin{array}{l}\text { Nervous } \\
\text { system }\end{array}$ & $\begin{array}{l}\text { Face } \\
\text { Beckwith- } \\
\text { Weidemann } \\
\text { syndrome }\end{array}$ \\
\hline Deemeh & AOA & 0 & 0 & 0 & 0 & 0 & 0 & $\begin{array}{l}\text { Poland } \\
\text { syndrome }\end{array}$ \\
{$[18]$} & ICSI & 1 & 0 & 1 & 0 & 0 & 0 & 0 \\
Miller & AOA $^{\text {a }}$ & 4 & 2 & 2 & 0 & 0 & 0 & 1 \\
{$[15]$} & ICSI $^{\text {b }}$ & 8 & 5 & 3 & 2 & 3 & 1 & 0 \\
Li B $[17]$ & AOA & 2 & 0 & 0 & 0 & 0 & 0 & 0 \\
& ICSI & 20 & 1 & 3 & 0 & 0 & 3 & 0 \\
\hline
\end{tabular}

ICSI intracytoplasmic sperm injection, $A O A$ artificial oocyte activation

${ }^{a}$ In the AOA group, one case with several structural defects (dysplastic kidney, reflux, ventricular septal defect) and another case with ventricular septal defect, interrupted inferior vena cava and short thumb with low insertion of right hand

${ }^{b}$ In the ICSI group, one case with both hypospadias and ventricular septal defect

\section{Meta analysis}

Overall, Fig. 2 showed that there was no significant difference between conventional ICSI and ICSI-AOA group in terms of birth defects risk $(\mathrm{RR}=1.27$, 95\% CI 0.70 2.28, $p=0.43)$. The individual risk estimates for these studies ranged from $0.23-3.97$. We found no evidence of heterogeneity of risk ratio among these five studies $(P=$ 0.52). Publication bias was not assessed, since the funnel plot analysis was not performed due to the limited study numbers. Sensitivity analysis were performed to assess the influence of each included study on the pooled risk estimate by repeating the meta-analysis after omitting each study in turn. The results suggested that the combined RR was not dominated by any single study.

The procedure of AOA mainly affect the time of meiotic spindle orientation and completion of meiosis [25]. Therefore, a subgroup analysis was performed based on the birth defects types (CA or NCA). Figure 3 depicted the results from the fix-effects model combining the RR for CA and NCA. Overall, there were not evidently increased risks for $\mathrm{CA}(\mathrm{RR}=1.49 ; 95 \% \mathrm{CI}: 0.37-6.07)$ and NCA (RR $=1.24$; 95\%CI: 0.64-2.40). Substantial heterogeneity was not found in these outcomes (all $\mathrm{I}^{2} \leq 30 \%$ ).

\section{Discussion}

\section{Main findings}

We performed a standard meta-analysis to estimate the risk of birth defects in children conceived by ICSI-AOA and conventional ICSI. This meta-analysis included a total of 5506 conventional ICSI infants and 316 ICSIAOA infants spread over 5 studies. Findings from the present study indicated that there is no significant difference in birth defects between conventional ICSI and ICSI-AOA. According to the type of birth defects, we divided birth defects into CA and NCA. The difference in the prevalence of defects types was not significant. What's more, substantial heterogeneity was not observed in all outcomes.

\section{Interpretation}

ART is generally considered as a safe method for infertile couples. However, the rapid progress of technologies, as well as the ever-growing demand for ART, make it more important to continually monitor its safety [30]. Since the first report of AOA in 1997 [31], multiple studies have reported increased fertilization and pregnancy rate with the application of AOA as an effective treatment for failed or low fertilization after conventional ICSI [32-34]. Subsequently, the safety of ICSIAOA has also gained great attention because of the additional manipulation to both oocytes and sperms.

Previous studies have evaluated the bio-safety of ionomycin, strontium chloride and other AOA agents in mice, and no adverse effects were shown on development of murine embryos and health of the filial generation $[35,36]$. However, there were no similar studies carried out in human beings. In some retrospective studies which followed up 38, 32, 25, 22, 16, 10 babies from

Table 3 Number of children with types of birth defects from included studies

\begin{tabular}{|c|c|c|c|c|c|c|}
\hline \multirow[t]{2}{*}{ Author(s) } & \multicolumn{2}{|c|}{ Total number of children } & \multicolumn{2}{|c|}{ Non-chromosomal aberrations } & \multicolumn{2}{|c|}{ Chromosomal aberrations } \\
\hline & ICSI & AOA & ICSI & AOA & ICSI & AOA \\
\hline Deemeh [18] & 89 & 79 & 2 & 0 & 0 & 0 \\
\hline Nakajo [16] & 1978 & 62 & 67 & 1 & 8 & 1 \\
\hline Miller [15] & 426 & 62 & 19 & 6 & 7 & 0 \\
\hline Li B [17] & 2442 & 95 & 30 & 2 & 1 & 0 \\
\hline
\end{tabular}

ICSI intracytoplasmic sperm injection, $A O A$ artificial oocyte activation 


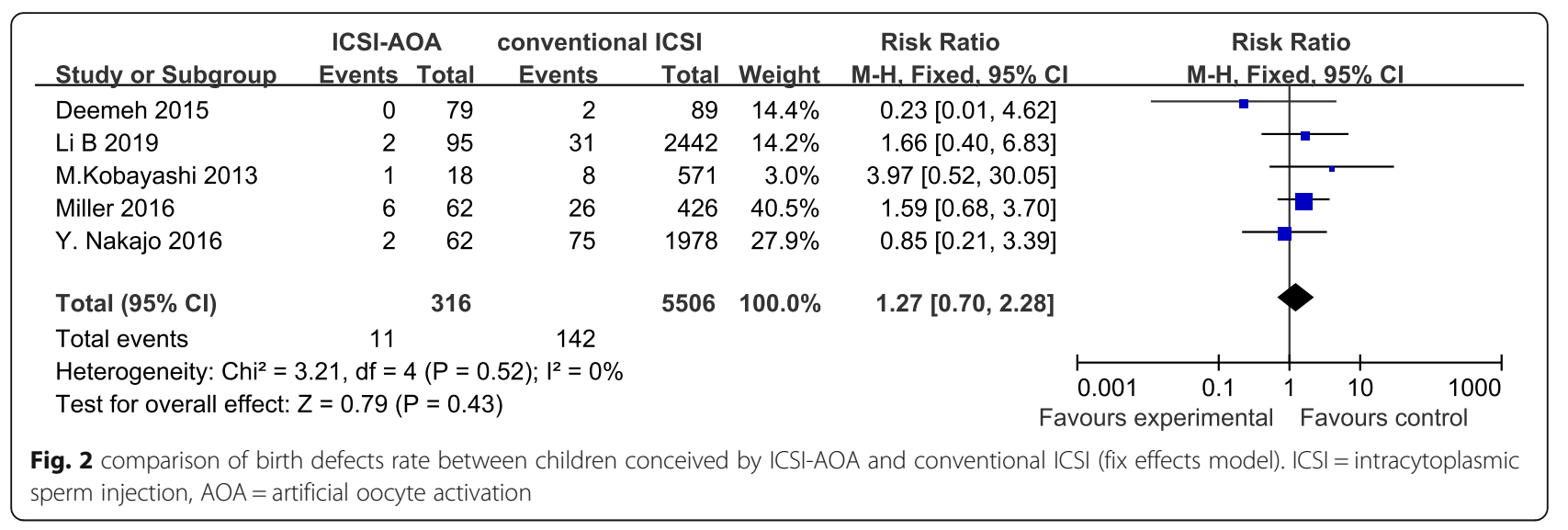

AOA, respectively, no birth defects were reported [21, 22, 37-40]. Nevertheless, Ileana Mateizel et al. reported a cohort of 47 babies delivered after AOA (31 singles and 16 twins) that 3 children were diagnosed with major malformations [19]. Total major malformation rate was $6.3 \%$ which was higher than that as described previously in a cohort of children born after using ejaculated sperm ICSI in the same center (4.1\%) [41], though it was not significantly different. Another study followed 21 children who were born after AOA for 3-10 years found that they all laid within expected ranges regarding neurodevelopmental, intelligence, language and communication skills, however, 3 children (14.3\%) were diagnosed with birth defects at toddler age [20].So, although these two studies were not included in our meta-analysis due to lack of comparative data to conventional ICSI, the application of AOA still should be cautious and the safety of AOA needs to be concerned. Whereas, given the small sample size, these results need to be interpreted prudently.

In this meta-analysis, no sufficient evidence of an increased risk of major birth defects and malformation

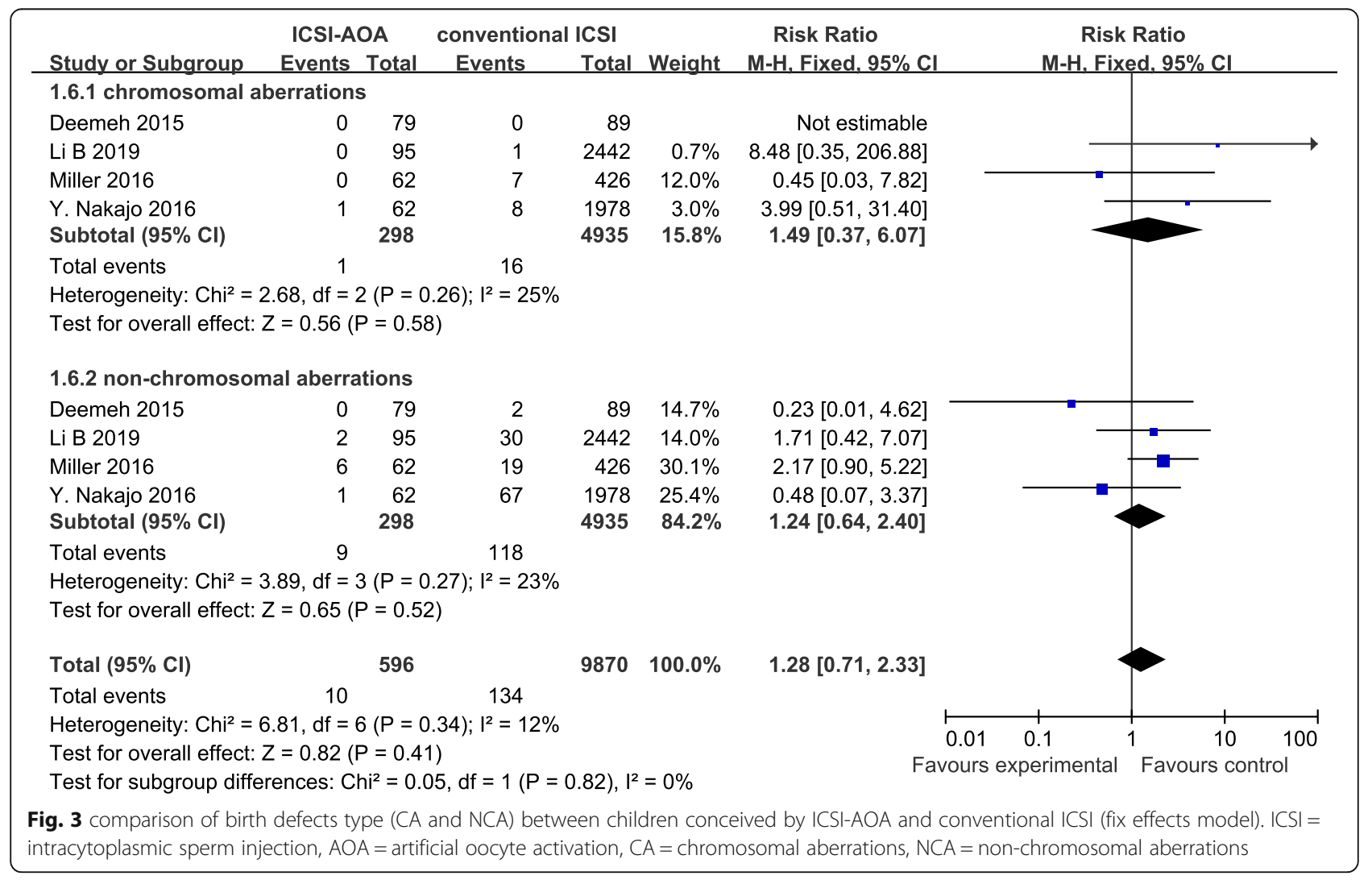


types after ICSI-AOA as compared with conventional ICSI was found which may imply that AOA does not appear to impose a higher risk of abnormality and AOA may be considered as a safe method for clinical application in ART. The risk of birth defects may be related to the ICSI procedures or an underlying male/female factor rather than AOA. A meta-analysis conducted on 46 studies revealed that children conceived by either IVF and/or ICSI are at a significantly increased risk for birth defects [42]. Sutcliffe AG et al. showed that there were significantly more birth defects among children born from fathers with oligozoospermia than in other children conceived by ICSI in a UK case-control study [43]. Other reports also suggested that the risk of passing on genetic defects to the offspring is highest in men with oligozoospermia [44, 45]. As for female aspects, the incidence of birth defects may associate with maternal age, infertility factors and drugs to stimulate follicular development and ovulation [46, 47]. Furthermore, most of the included studies didn't include the terminal of pregnancy due to fetal defect, only evaluated the incidence of birth defects in live-born infants, which may lead to underestimating the prevalence of birth defects.

It is interesting that the birth defects after ICSI-AOA and conventional ICSI in our study both had an apparently high proportion of congenital heart defects and genitourinary defects, although numbers were too small for statistical comparisons. Additional larger studies need to be conducted to assess the effect of extra manipulation on embryo and fetal development.

\section{Strengths and limitation}

So far, no meta-analyses have been conducted to explore the association between the AOA infants and birth defects and the possible effect of AOA on the development of embryo chromosome. The present study, to the best of our knowledge, was the first meta-analysis to address these issues. Although only five researches were included, this meta-analysis was really needed in order to pre-estimate the risk of AOA with the increasing concerns on the safety of AOA. An improved understanding of these issues may be beneficial for the development and application of AOA and provide clinicians evidencebased support in patient counseling in assisted reproductive technology.

A study like this will inevitably reveal certain limitations. Firstly, due to its specific indication, the number of patients that may benefit from AOA is rather small, leading to a low number of children born after transfer of an embryo obtained after oocyte activation [19]. So, the association between the risk of birth defects and AOA was limited. As a result, we did not evaluate the safety of the offspring through other subgroup analyses, such as AOA indications, malformed organ systems, oocyte activation methods, fresh or frozen embryo transfer and so on. For such a solid conclusion, more followup studies on children conceived by AOA were necessary to further confirm its safety. Secondly, birth defects were only diagnosed at birth in most of the studies [1618,28 ] and a systemic karyotype evaluation was not performed. Some chromosomal anomalies or minor defects, such as certain sex chromosomal anomalies and balanced structural anomalies may go under detected or only be detected in later life. Previous study has reported that the prevalence of these chromosomal anomalies was higher in ICSI pregnancies compared with IVF [42]. Therefore, we cannot exclude a possibility that children conceived by AOA have an elevated prevalence of chromosomal anomalies. In addition, only one included study [16] conducted a six-year follow-up, and examined the cognitive development of children conceived by AOA. So, our study lacked the subgroup analysis about the mental development in AOA infants, which can evaluate the safety of AOA more comprehensively. Thirdly, ideally all pregnancies, also miscarriages and induced abortions due to congenital malformations or chromosomal abnormalities, should be included in the congenital malformation rate. Moreover, in comparison with singletons, twins have higher risks of adverse outcomes including preterm birth, low birth weight and birth defects $[48,49]$. Therefore, it is essential to analyze the birth defects rate in singletons and twins, respectively. Whereas, most included studies lacked detailed information about birth defects in these aspects, which was not able to find the association between birth defects and these potential risk factors.

Therefore, large-scale and long-term follow-up studies on the prevalence of AOA-associated birth defects and defects types need to be addressed to support our findings continually in the future. In addition, potential risks of AOA such as mutagenic and epigenetic effects on oocytes and embryos should also be investigated further.

\section{Conclusion}

In conclusion, we did not find a significantly increased risk in terms of birth defects and malformation types in children conceived by ICSI-AOA compared with conventional ICSI in an enlarged sample size analysis. There are still concerns related to the safety of ICSI-AOA and more well-conducted observational studies are needed.

\section{Abbreviations}

ICSI-AOA: Artificial oocyte activation; ICSI: Intracytoplasmic sperm injection; RR: Risk ratios; Cl: Confidence intervals; ART: Assisted reproductive technology; IVF: In vitro fertilization; TFF: Total fertilization failure; CA: Chromosomal aberrations; NCA: Non-chromosomal aberrations; PRIS MA: Preferred Reporting Items for Systematic Reviews and Meta-Analyses; ejICSI: ejaculated sperm ICSI; TESE: Testicular sperm extraction; IVM: In vitro maturation 


\section{Acknowledgements}

Not applicable.

\section{Authors' contributions}

$R L, L Z$ and $\sqcup$ contributed to the study design. QY and SH contributed to the data acquisition and analysis. RL contributed to the data interpretation. $\mathrm{RL}$ and MW contributed to the article writing. All authors made critical revisions and gave final approval of the version to be published.

\section{Funding}

None.

\section{Availability of data and materials}

The current study was based on results of relevant published studies.

\section{Ethics approval and consent to participate}

Not applicable.

\section{Consent for publication}

Not applicable.

\section{Competing interests}

The author declare that they have no conflict of interest.

Received: 6 August 2020 Accepted: 6 December 2020 Published online: 11 December 2020

\section{References}

1. Palermo G, Joris H, Devroey P, Van Steirteghem AC. Pregnancies after intracytoplasmic injection of single spermatozoon into an oocyte. Lancet. 1992:340:17-8

2. Heindryckx B, Van der Elst J, De Sutter P, Dhont M. Treatment option for sperm- or oocyte-related fertilization failure: assisted oocyte activation following diagnostic heterologous ICSI. Hum Reprod. 2005;20:2237-41.

3. Esfandiari N, Faved MH, Gotlieb L, Casper RF. Complete failed fertilization after intracytoplasmic sperm injection - analysis of 10 years' data. Int J Fertil Womens Med. 2005:50:187-92.

4. Flaherty SP, Payne D, Matthews CD. Fertilization failures and abnormal fertilization after intracytoplasmic sperm injection. Hum Reprod. 1998;13: 155-64.

5. Swain JE, Pool TB. ART failure: oocyte contributions to unsuccessful fertilization. Hum Reprod Update. 2008:14:431-46.

6. Miyazaki S, Ito M. Calcium signals for egg activation in mammals. J Pharmacol Sci. 2006:100:545-52.

7. Ramadan WM, Kashir J, Jones C, Coward K. Oocyte activation and phospholipase C zeta (PLC zeta): diagnostic and therapeutic implications for assisted reproductive technology. Cell Commun Signal. 2012;10:12.

8. Liu J, Nagy Z, Joris H, Tournaye H, Devroey P, Van Steirteghem A. Successful fertilization and establishment of pregnancies after intracytoplasmic sperm injection in patients with globozoospermia. Hum Reprod. 1995;10:626-9.

9. Rawe VY, Olmedo SB, Nodar FN, Doncel GD, Acosta AA, Vitullo AD. Cytoskeletal organization defects and abortive activation in human oocytes after IVF and ICSI failure. Mol Hum Reprod. 2000;6:510-6.

10. Ebner $\mathrm{T}$, Montag $\mathrm{M}, \mathrm{Montag} \mathrm{M}$, Van der Ven $\mathrm{K}$, Van der Ven $\mathrm{H}$, Ebner $\mathrm{T}$, Shebl O, Oppelt P, Hirchenhain J, Kruessel J, et al. Live birth after artificial oocyte activation using a ready-to-use ionophore: a prospective multicentre study. Reprod BioMed Online. 2015:30:359-65.

11. Sfontouris IA, Nastri CO, Lima MLS, Tahmasbpourmarzouni E, Raine-Fenning $\mathrm{N}$, Martins WP. Artificial oocyte activation to improve reproductive outcomes in women with previous fertilization failure: a systematic review and meta-analysis of RCTs. Hum Reprod. 2015;30:1831-41.

12. Kashir J, Heindryckx B, Jones C, De Sutter P, Parrington J, Coward K. Oocyte activation, phospholipase C zeta and human infertility. Hum Reprod Update. 2010;16:690-703.

13. Nasr-Esfahani MH, Deemeh MR, Tavalaee M. Artificial oocyte activation and intracytoplasmic sperm injection. Fertil Steril. 2010;94:520-6

14. Vanden Meerschaut F, Nikiforaki D, Heindryckx B, De Sutter P. Assisted oocyte activation following ICSI fertilization failure. Reprod BioMed Online. 2014;28:560-71.
15. Miller N, Biron-Shental T, Sukenik-Halevy R, Klement AH, Sharony R, Berkovitz A. Oocyte activation by calcium ionophore and congenital birth defects: a retrospective cohort study. Fertil Steril. 2016;106:590.

16. Nakajo Y, Shibasaki S, Matsukawa N, Aono N, Toya M, Doshida M, Hashimoto T, Kyono K. Follow-up of children born after new technologies: testicular sperm extraction (TESE), in vitro maturation (IVM), and artificial oocyte activation (AOA). Hum Reprod. 2016;31:109.

17. Li B, Zhou Y, Yan Z, Li M, Xue S, Cai R, Fu Y, Hong Q, Long H, Yin M, et al. Pregnancy and neonatal outcomes of artificial oocyte activation in patients undergoing frozen-thawed embryo transfer: a 6-year population-based retrospective study. Arch Gynecol Obstet. 2019;300:1083-92.

18. Deemeh MR, Tavalaee M, Nasr-Esfahani MH. Health of children born through artificial oocyte activation: a pilot study. Reprod Sci. 2015;22:322-8.

19. Mateizel I, Verheyen G, Van de Velde H, Tournaye H, Belva F. Obstetric and neonatal outcome following ICSI with assisted oocyte activation by calcium ionophore treatment. J Assist Reprod Genet. 2018;35:1005-10.

20. Vanden Meerschaut F, D'Haeseleer $E$, Gysels $H$, Thienpont $Y$, Dewitte $G$, Heindryckx B, Oostra A, Roeyers H, Van Lierde K, De Sutter P. Neonatal and neurodevelopmental outcome of children aged 3-10 years born following assisted oocyte activation. Reprod BioMed Online. 2014;28:54-63.

21. Yoon HJ, Bae IH, Kim HJ, Jang JM, Hur YS, Kim HK, Yoon SH, Lee WD, Lim $\mathrm{JH}$. Analysis of clinical outcomes with respect to spermatozoan origin after artificial oocyte activation with a calcium ionophore. J Assist Reprod Genet. 2013;30:1569-75.

22. Li J, Zheng X, Lian Y, Li M, Lin S, Zhuang X, Chen L, Liu P, Qiao J. Artificial oocyte activation improves cycles with prospects of ICSI fertilization failure: a sibling oocyte control study. Reprod BioMed Online. 2019;39:199-204.

23. Van Steirteghem A, Bonduelle M, Devroey P, Liebaers I. Follow-up of children born after ICSI. Hum Reprod Update. 2002;8:111-6.

24. Bonduelle M, Van Assche E, Joris H, Keymolen K, Devroey P, Van Steirteghem A, Liebaers I. Prenatal testing in ICSI pregnancies: incidence of chromosomal anomalies in 1586 karyotypes and relation to sperm parameters. Hum Reprod. 2002;17:2600-14.

25. Terada Y, Hasegawa H, Takahashi A, Ugajin T, Yaegashi N, Okamura K. Successful pregnancy after oocyte activation by a calcium ionophore for a patient with recurrent intracytoplasmic sperm injection failure, with an assessment of oocyte activation and sperm centrosomal function using bovine eggs. Fertil Steril. 2009:91:935.e11-4.

26. Liberati A, Altman DG, Tetzlaff J, Mulrow C, Gotzsche PC, loannidis JPA, Clarke M, Devereaux PJ, Kleijnen J, Moher D. The PRISMA statement for reporting systematic reviews and meta-analyses of studies that evaluate health care interventions: explanation and elaboration. J Clin Epidemiol. 2009:62:e1-34.

27. Wells GA, Shea B, O'Connell D, Peterson J, Welch V, Losos M, Tugwell M. The Newcastle-Ottawa Scale (NOS) for assessing the quality of nonrandomised studies in meta-analyses. 2015. http://www.ohri.ca/ programs/clinical_epidemiology/oxford.asp. Accessed 13 Oct 2020.

28. Kobayashi M, Yoshida A, Tanigiwa S, Seida K, Suzuki H, Tanaka M. Clinical outcome following ICSI with assisted oocyte activation (ionomycin or electroporation). Hum Reprod. 2013;28:100.

29. Bernardini L, Gianaroli L, Fortini D, Conte N, Magli C, Cavani S, Gaggero G, Tindiglia C, Ragni N, Venturini PL. Frequency of hyper-, hypohaploidy and diploidy in ejaculate, epididymal and testicular germ cells of infertile patients. Hum Reprod. 2000:15:2165-72.

30. Kissin DM, Jamieson DJ, Barfield WD. Monitoring health outcomes of assisted reproductive technology. N Engl J Med. 2014:371:91-3.

31. Rybouchkin AV, Van der Straeten F, Quatacker J, De Sutter P, Dhont M. Fertilization and pregnancy after assisted oocyte activation and intracytoplasmic sperm injection in a case of round-headed sperm associated with deficient oocyte activation capacity. Fertil Steril. 1997;68 $1144-7$.

32. Heindryckx B, De Gheselle S, Gerris J, Dhont M, De Sutter P. Efficiency of assisted oocyte activation as a solution for failed intracytoplasmic sperm injection. Reprod BioMed Online. 2008;17:662-8

33. Fawzy M, Emad M, Mahran A, Sabry M, Fetih AN, Abdelghafar H, Rasheed S. Artificial oocyte activation with $\mathrm{SrCl} 2$ or calcimycin after ICSI improves clinical and embryological outcomes compared with ICSI alone: results of a randomized clinical trial. Hum Reprod. 2018;33:1636-44.

34. Murugesu S, Saso S, Jones BP, Bracewell-Milnes T, Athanasiou T, Mania A, Serhal P, Ben-Nagi J. Does the use of calcium ionophore during artificial oocyte activation demonstrate an effect on pregnancy rate? A metaanalysis. Fertil Steril. 2017;108:468-482.e463. 
35. Heytens E, Soleimani R, Lierman S, De Meester S, Gerris J, Dhont M, Van der Elst J, De Sutter P. Effect of ionomycin on oocyte activation and embryo development in mouse. Reprod BioMed Online. 2008;17:764-71.

36. Vanden Meerschaut F, Nikiforaki D, De Roo C, Lierman S, Qian C, SchmittJohn T, De Sutter P, Heindryckx B. Comparison of pre- and postimplantation development following the application of three artificial activating stimuli in a mouse model with round-headed sperm cells deficient for oocyte activation. Hum Reprod. 2013;28:1190-8.

37. Montag M, Koster M, van der Ven $\mathrm{K}$, Bohlen $\mathrm{U}$, van der Ven $\mathrm{H}$. The benefit of artificial oocyte activation is dependent on the fertilization rate in a previous treatment cycle. Reprod BioMed Online. 2012;24:521-6.

38. Ebner T, Oppelt P, Wober M, Staples P, Mayer RB, Sonnleitner U, Bulfon-Vogl S, Gruber I, Haid AE, Shebl O. Treatment with $\mathrm{Ca} 2+$ ionophore improves embryo development and outcome in cases with previous developmental problems: a prospective multicenter study. Hum Reprod. 2015;30:97-102.

39. Mansour R, Fahmy I, Tawab NA, Kamal A, El-Demery Y, Aboulghar M, Serour G. Electrical activation of oocytes after intracytoplasmic sperm injection: a controlled randomized study. Fertil Steril. 2009;91:133-9.

40. Ebner T, Koster M, Shebl O, Moser M, Van der Ven H, Tews G, Montag M. Application of a ready-to-use calcium ionophore increases rates of fertilization and pregnancy in severe male factor infertility. Fertil Steril. 2012; 98:1432-7.

41. Belva F, De Schrijver F, Tournaye H, Liebaers I, Devroey P, Haentjens P, Bonduelle M. Neonatal outcome of 724 children born after ICSI using nonejaculated sperm. Hum Reprod. 2011;26:1752-8.

42. Wen J, Jiang J, Ding C, Dai J, Liu Y, Xia Y, Liu J, Hu Z. Birth defects in children conceived by in vitro fertilization and intracytoplasmic sperm injection: a meta-analysis. Fertil Steril. 2012;97:1331-7.

43. Sutcliffe AG, Taylor B, Saunders K, Thornton S, Lieberman BA, Grudzinskas $J G$. Outcome in the second year of life after in-vitro fertilisation by intracytoplasmic sperm injection: a UK case-control study. Lancet. 2001;357: 2080-4.

44. Kent-First MG, Kol S, Muallem A, Ofir R, Manor D, Blazer S, First N, ItskovitzEldor J. The incidence and possible relevance of Y-linked microdeletions in babies born after intracytoplasmic sperm injection and their infertile fathers. Mol Hum Reprod. 1996;2:943-50.

45. Stuppia L, Gatta V, Calabrese G, Guanciali Franchi P, Morizio E, Bombieri C, Mingarelli R, Sforza V, Frajese G, Tenaglia R, Palka G. A quarter of men with idiopathic oligo-azoospermia display chromosomal abnormalities and microdeletions of different types in interval 6 of Yq11. Hum Genet. 1998; 102:566-70.

46. Goldberg MF, Edmonds LD, Oakley GP. Reducing birth defect risk in advanced maternal age. JAMA. 1979;242:2292-4.

47. Lambert RD. Safety issues in assisted reproductive technology: aetiology of health problems in singleton ART babies. Hum Reprod. 2003;18:1987-91.

48. Dawson AL, Tinker SC, Jamieson DJ, Hobbs CA, Berry RJ, Rasmussen SA, Anderka M, Keppler-Noreuil KM, Lin AE, Reefhuis J. Twinning and major birth defects, National Birth Defects Prevention Study, 1997-2007. J Epidemiol Community Health. 2016;70:1114-21.

49. Chauhan SP, Scardo JA, Hayes E, Abuhamad AZ, Berghella V. Twins: prevalence, problems, and preterm births. Am J Obstet Gynecol. 2010;203: 305-15.

\section{Publisher's Note}

Springer Nature remains neutral with regard to jurisdictional claims in published maps and institutional affiliations.

Ready to submit your research? Choose BMC and benefit from:

- fast, convenient online submission

- thorough peer review by experienced researchers in your field

- rapid publication on acceptance

- support for research data, including large and complex data types

- gold Open Access which fosters wider collaboration and increased citations

- maximum visibility for your research: over $100 \mathrm{M}$ website views per year

At BMC, research is always in progress.

Learn more biomedcentral.com/submissions 